\title{
An Agribusiness development approach of beef cattle in selected areas of Bangladesh
}

P. K. Sarma

Bangladesh Agricultural University Research System (BAURES), Bangladesh Agricultural University, Mymensingh2202, Bangladesh, E-mail:sharmapk73@gmail.com

\begin{abstract}
The study was pursued to ascertain the existing internal and external factors, alternative strategies and priorities of the strategies applied in enhancing beef cattle agribusiness at Pabna and Sirajganj districts in Bangladesh. The primary data and present study were collected by employing various techniques such as survey, FGD, KII and observation methods. The total sample size was 180 which were selected through convenience sampling technique. The following analytical tools used were employed i) IFE-EFE analysis ii) SWOT analysis, iii) SWOT matrix, and iv) QSPM model. By analyzing all the factors from SWOT four strategies were developed to determine the beef cattle development. The best strategy was selected by using QSPM matrix. The results IFE is 2.610 , EFE is 2.438 and the total weighted score is 5.833 indicates that beef cattle sub-sector agribusiness are opportunity to explore their strengths and minimize their weaknesses. The beef cattle agribusiness development through the implementation of the integrated or contract farming that supported to backward and forward linkage and support services.
\end{abstract}

Keywords: Beef cattle agribusiness, Strategies, IFE-EFE Matrix, SWOT analysis

\section{Introduction}

Livestock agribusinesses play a significant role in our economy through contributing to poverty eradication by creating rural employment and to gear up the achievement of higher economic growth. Livestock is an integral component of agricultural economy of Bangladesh. Performing various functions as provisions of food, nutrition, income generation, savings, draft power, manure, fuel, transport and cultural function and earning foreign currency by exporting meat, hides and skin and value added waste products, etc. About $36 \%$ of the total animal protein comes from the livestock rest of them (64\%) come from poultry, fish and pluses. Bangladesh has huge number of livestock and poultry population with a very high density but low productivity. The country has about 23.4 million cattle, 1.45 million buffalo, 25.6 million goats, 3.16 million sheep, 221.30 million chicken and 41.23 million ducks (GOB, 2012). Beef cattle are the important and potential sub-sector to economic improvement, where this sub-sector has a strategic value in the fulfillments of human need that increases steadily along with the increasing of per capita income. The study aimed to examine the existing characteristics of the farmers, i.e. their social and economic characteristics in relation to the development of beef cattle farming, to determine factors influencing the policy of beef cattle farming, and to design the strategic plan. The study is intended to contribute information and ideas in relation to sustainable beef cattle farming and also provide inputs for policy makers to develop the management plan for beef cattle development in order to fulfill the national food security needs.

\section{Materials and Methods}

The study was conducted in Pabna and Sirajganj districts. Two Upazilas namely Shatia from Pabna and Raigonj from Sirajgonj districts were selected because of the concentration of beef cattle fattening activity. Total sample size was 180 including beef cattle producers and different agribusiness actors (i.e. live cattle traders, brokers, butcher - cum -meat traders, meat processor and beef by-products traders etc). Convenience sampling technique was used for selection of respondents of the study and questionnaires survey, FGD, KII and observation methods were adapted for collection of primary data. Secondary data were also collected from the various sources. Results of the analysis were presented in the form of tables and matrix form. Data were analyzed by using SPSS software.

In this study, the following techniques were used which were also used by David et al., (2009), Ananto et al.(2011) , Achmad et al. (2012) and Prastuti et al. (2012) . 


\section{Strategy Formulation frameworks}

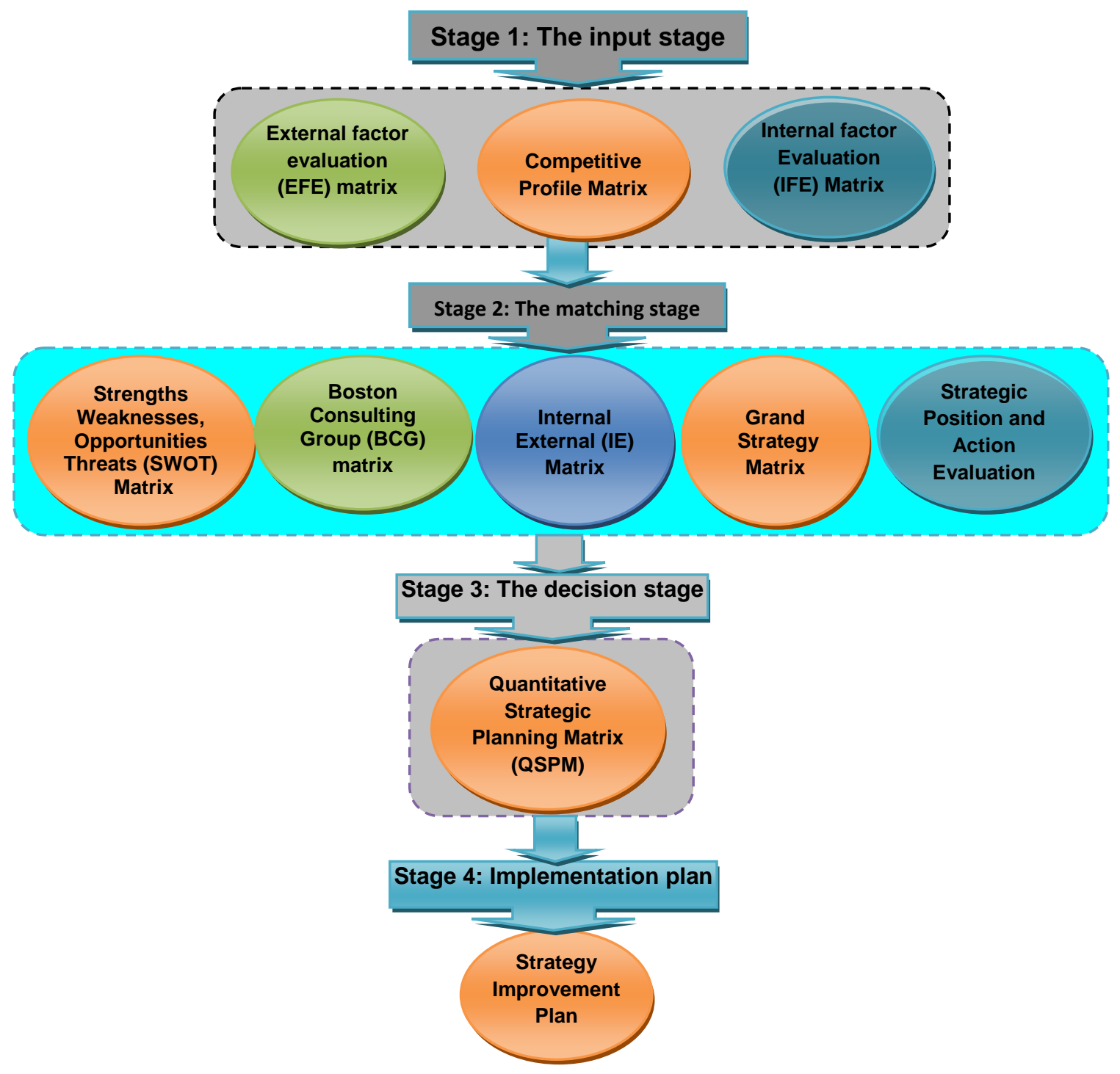

\section{Results and Discussion}

The results of the present study are presented in following heading to develop the beef cattle agribusiness strategies.

\section{Internal Factor Evaluation Matrix (IFE matrix):}

IEF Matrix is a strategic management tool used for evaluation of strengths and weaknesses for internal factors affecting the development of beef cattle in study areas. From Table 1, it can be seen that the highest weight score is 0.256 which implies that factors that are effective are innovation. These are important internal factors which are effective to develop the beef cattle in northern Bangladesh to support the food estate program. The result also shows that the sum of total weight score is 2.610. Therefore, it can be concluded that the strategy of developing beef cattle in northern Bangladesh has been effective in using the strength and minimizing weakness factors which had contributed to negative impact similar to Gunawan (2001). Suryana (2009) in his study also stated that in order to enhance the role of beef cattle as meat suppliers and livestock income sources, it is advisable to apply an intensive maintenance system with an improved feed management and improved quality of cattle with disease control. 
Table 1. IFE (Internal Factor Evaluations) Matrix

\begin{tabular}{|c|c|c|c|c|}
\hline \multicolumn{2}{|c|}{ Internal Strategies Factor } & $\begin{array}{c}\text { Weight } \\
\{\text { Coefficient } \\
\text { importance }(0-1)\}\end{array}$ & $\begin{array}{c}\text { Rating } \\
(1-4)\end{array}$ & $\begin{array}{c}\text { Score } \\
\text { (coefficient } \\
\text { * rank) }\end{array}$ \\
\hline \multicolumn{5}{|c|}{ Strength } \\
\hline S1 & Domestically produced & 0.064 & 4 & 0.256 \\
\hline $\mathrm{S} 2$ & Beef cattle are renewable natural & 0.059 & 4 & 0.236 \\
\hline S3 & Large number of labour force. & 0.057 & 4 & 0.228 \\
\hline S4 & Government is committed to develop the sector & 0.054 & 4 & 0.216 \\
\hline S5 & High interest beef cattle rearing among respondents & 0.052 & 4 & 0.208 \\
\hline S6 & $\begin{array}{l}\text { Rapid growth supermarkets, superstore, restaurant and tourist } \\
\text { hotel. }\end{array}$ & 0.065 & 3 & 0.195 \\
\hline S7 & Availability of innovative technology & 0.056 & 3 & 0.168 \\
\hline S8 & Favorable geographical location, climate and breed & 0.046 & 3 & 0.138 \\
\hline S9 & Consumers preference for beef & 0.041 & 3 & 0.123 \\
\hline \multicolumn{2}{|c|}{ Total Strength } & & & 1.768 \\
\hline \multicolumn{5}{|c|}{\begin{tabular}{|l|} 
Weakness \\
\end{tabular}} \\
\hline W1 & Lack of feed and fodder & 0.064 & 2 & 0.128 \\
\hline W2 & Lack of meat processing knowledge & 0.063 & 2 & 0.126 \\
\hline W3 & Prevalence of Anthrax diseases & 0.058 & 2 & 0.116 \\
\hline W4 & Lack of sufficient and proper slaughter houses & 0.055 & 2 & 0.110 \\
\hline W5 & Limitations of supporting institutions related to beef cattle & 0.048 & 2 & 0.096 \\
\hline W6 & Inadequate institutional support & 0.048 & 2 & 0.096 \\
\hline W7 & Lack of working capital & 0.064 & 1 & 0.064 \\
\hline W8 & Limited number of local cattle breed & 0.053 & 1 & 0.053 \\
\hline W9 & No organized marketing system & 0.053 & 1 & 0.053 \\
\hline \multicolumn{2}{|c|}{ Total Weakness } & & & 0.842 \\
\hline \multicolumn{2}{|c|}{ Total } & 1.00 & & 2.610 \\
\hline
\end{tabular}

Source: Field Survey 2014

As for the improvement of genetic quality of the female calves, it is suggested to keep them in the breeding area for subsequent use as grading up cattle. Increased interest and motivation of cattle ranchers to expand their business can be facilitated through incentives in production.

\section{External Factor Evaluation Matrix (EFE Matrix):}

EFE matrix is used the weighting scoring system to identify the value opportunity weight and threat for beef cattle producers in study area. Based on external evaluation matrix the results (Table 2) showed that the total score for the opportunity factor is 1.725 and the threat is 0.713 and total score 2.438 indicate beef cattle agribusiness has a significant opportunity while minimizing threat in the study area which is similar to Achmad M. et al., (2012) and Prastit.

R.A. et al. (2012). This is consistent with Nugroho (2006) findings which states that the development of animal husbandry as a part of agricultural development will be associated with the reorientation of agricultural development policy. Animal husbandry development has new paradigms, namely alignment to people in general, responsibility delegation, structural change, and people empowerment. Therefore, it is necessary to formulate strategies and policies that are comprehensive, systematic, integrated both vertically and horizontally competitive, sustainable and decentralized.

\section{Internal External Matrix (IE Matrix)}

IE matrix is a simple analytical framework that is based on final summary of internal and external factors (IFE, EFE). It can specify appropriate strategy for the beef cattle agribusiness. Based on the evaluation of internal factors (IFE) and external factors (EFE) of the agribusiness, the following results were obtained:

Final score of internal factors evaluation matrix (IFE): 2.610

Final score of external factors evaluation matrix (EFE): 2.438 
Table 2. EFE (External Factor Evaluations) Matrix

\begin{tabular}{|c|c|c|c|c|}
\hline \multicolumn{2}{|c|}{ External Strategies Factor } & $\begin{array}{c}\text { Weight } \\
\{\text { Coefficient } \\
\text { importance }(0-1)\}\end{array}$ & $\begin{array}{c}\text { Rating } \\
(1-4)\end{array}$ & $\begin{array}{l}\text { Score } \\
\text { (coefficient* } \\
\text { rank) }\end{array}$ \\
\hline \multicolumn{5}{|c|}{ Opportunities } \\
\hline 01 & Potential demand for beef over the country. & 0.071 & 4 & 0.284 \\
\hline $\mathrm{O} 2$ & Government support to develop beef cattle & 0.065 & 4 & 0.260 \\
\hline $\mathrm{O} 3$ & Domestic and foreign private sector interested to invest. & 0.074 & 3 & 0.222 \\
\hline $\mathrm{O} 4$ & High potential for profitable slaughter and processing business & 0.051 & 4 & 0.204 \\
\hline $\mathrm{O5}$ & High value addition potential & 0.067 & 3 & 0.201 \\
\hline O6 & $\begin{array}{l}\text { Consumers express more interest and are willing to pay for } \\
\text { safe food }\end{array}$ & 0.061 & 3 & 0.183 \\
\hline $\mathrm{O7}$ & $\begin{array}{l}\text { Domestic oriented processing plants have options to } \\
\text { differentiate and diversify their products to satisfy some of the } \\
\text { untapped markets }\end{array}$ & 0.055 & 3 & 0.165 \\
\hline O8 & Labor intensive and employment opportunities & 0.041 & 4 & 0.164 \\
\hline O9 & Scope exists for developing backward and forward linkage. & 0.014 & 3 & 0.042 \\
\hline \multicolumn{2}{|c|}{ Total Opportunities } & & & 1.725 \\
\hline \multicolumn{5}{|c|}{ Threats } \\
\hline T1 & Low productivity & 0.064 & 2 & 0.128 \\
\hline T2 & Increase in feed prices & 0.061 & 2 & 0.122 \\
\hline T3 & Increase in cattle prices & 0.046 & 2 & 0.092 \\
\hline T4 & Absence of pasture lands & 0.041 & 2 & 0.082 \\
\hline T5 & Poor access to credit & 0.065 & 1 & 0.065 \\
\hline T6 & High transportation cost (Illegal toll for cattle marketing) & 0.063 & 1 & 0.063 \\
\hline T7 & $\begin{array}{l}\text { Beef cattle smuggling and Indian traders are selling cattle on } \\
\text { credit }\end{array}$ & 0.061 & 1 & 0.061 \\
\hline T8 & Spread of cattle diseases & 0.057 & 1 & 0.057 \\
\hline T9 & $\begin{array}{l}\text { Lack of veterinary check of animal before and after slaughter } \\
\text { and low hygienic handling the meat lead to health risk for } \\
\text { consumers }\end{array}$ & 0.043 & 1 & 0.043 \\
\hline \multicolumn{2}{|c|}{ Total Threats } & & & 0.713 \\
\hline \multicolumn{2}{|l|}{ Total } & 1.000 & & 2.438 \\
\hline
\end{tabular}

Source: Field Survey 2014

Here IFE>EFE which indicates great opportunities to formulate the effective strategies for exploiting their strengths and minimize the weaknesses which is similar to Achmad et al. (2009) and Riston (2008). Based on the research on model policy for beef cattle development, Achmad et al. (2009) found the score of the internal and external factors was 2.603 and 3.457, respectively. They point out that the government policy should be aimed at intensive programs, such as market penetration, market development and developing products. The other government policy should also be aimed at integration programs such as backward integration, forward integration and product integration.

\section{Formulating Alternative Strategies}

Here different types of strategies were transferred to the strategic planning table after the examination of specific components of SWOT. The SWOT model is comprised of a two-dimensional coordinate table; each of its four areas is the maker of a group of strategies.

Based on various findings of SWOT analysis, four strategies are formulated which are presented in Strategic Planning Table (Table 3) and are described below.

SO strategy or Aggressive: SO strategy was formulated by maximum use of environmental opportunities with application of strengths of the beef cattle agribusiness.

ST strategy or competitive: ST strategy was generated by using strengths of the beef cattle agribusiness to avoid facing threats. 
WO Strategy or conservative: WO strategy was formulated by considering the potential advantages latent in environmental opportunities to make up for the weaknesses.

WT Strategy or defensive: WT strategy was formulated by considering minimizing loss from threats and weaknesses

Table 3. Strategic planning table for alternative strategies

\begin{tabular}{|c|c|c|}
\hline & $\begin{array}{l}\text { Strength } \\
\text { S1. Domestically produced } \\
\text { S2. Beef cattle are renewable natural } \\
\text { S3. Large number of labour force. } \\
\text { S4. Government is committed to develop the } \\
\text { sector } \\
\text { S5. High interest beef cattle rearing among } \\
\text { respondents } \\
\text { S6. Rapid growth supermarkets, superstore, } \\
\text { restaurant and tourist hotel. } \\
\text { S7. Availability of innovative technology } \\
\text { S8. Favorable geographical location, climate } \\
\text { and breed } \\
\text { S9. Consumers preference for beef }\end{array}$ & $\begin{array}{l}\text { Weakness } \\
\text { W1. Lack of feed and fodder } \\
\text { W2. Lack of meat processing } \\
\text { knowledge } \\
\text { W3. Prevalence of Anthrax diseases } \\
\text { W4. Lack of sufficient and proper } \\
\quad \text { slaughter houses } \\
\text { W5. Limitations of supporting } \\
\text { institutions related to beef cattle } \\
\text { W6. Inadequate institutional support } \\
\text { W7. Lack of working capital } \\
\text { W8. Limited number of local cattle } \\
\text { breed } \\
\text { W9. No organized marketing system }\end{array}$ \\
\hline $\begin{array}{l}\text { Opportunities } \\
\text { O1. Potential demand for beef over the } \\
\text { country. } \\
\text { O2. Government support to develop beef } \\
\text { cattle } \\
\text { O3. Domestic and foreign private sector } \\
\text { interested to invest. } \\
\text { O4. High potential for profitable slaughter } \\
\text { and processing business } \\
\text { O5. High value addition potential } \\
\text { O6. Consumers express more interest } \\
\text { and are willing to pay for safe food } \\
\text { O7. Domestic oriented processing plants } \\
\text { have options to differentiate and } \\
\text { diversify their products to satisfy } \\
\text { some of the untapped markets } \\
\text { O8. Labor intensive and employment } \\
\text { opportunities } \\
\text { O9. Scope exists for developing } \\
\text { backward and forward linkage. } \\
\end{array}$ & $\begin{array}{l}\text { SO Strategies (Aggressive) based on this } \\
\text { sector's advantages use external } \\
\text { environment's pleasant opportunities: } \\
\text { SO1. (S1,S2,S3,S4,O1,O2,O3,O4) } \\
\text { Developing an integration strategy involving } \\
\text { farmers, value chain actors and meat } \\
\text { processing industries. This can improve } \\
\text { productivity through transferring beef fattening } \\
\text { technologies, provide support services and } \\
\text { sustainable market linkage. Developed new } \\
\text { meat processing farm or abattoirs by PPP } \\
\text { model in producing areas and determining } \\
\text { strategies for marketing with a goal of } \\
\text { increasing domestic and foreign markets } \\
\text { share. Short-term strategy }\end{array}$ & $\begin{array}{l}\text { WO Strategies(conservative)- by } \\
\text { improving sector's disadvantages use } \\
\text { external environment's pleasant } \\
\text { opportunities } \\
\text { WO1. (W3, W4, W5, O1, O2,O6) } \\
\text { Develop policy on sustainable intensive } \\
\text { and semi-intensive beef cattle } \\
\text { production by optimizing the principles } \\
\text { of low external input sustainable beef } \\
\text { cattle based industry and zero waste } \\
\text { approaches of by-products and also } \\
\text { development contract framing model } \\
\text { with provision of self help group } \\
\text { formation, skill development, provide } \\
\text { input and finally market linkage. } \\
\text { Medium-term strategy }\end{array}$ \\
\hline $\begin{array}{l}\text { Threats } \\
\text { T1. Low productivity } \\
\text { T2. Increase in feed prices } \\
\text { T3. Increase in cattle prices } \\
\text { T4. Absence of pasture lands } \\
\text { T5.Poor access to credit } \\
\text { T6. High transportation cost } \\
\text { (Illegal toll for cattle } \\
\text { marketing) } \\
\text { T7. Beef cattle smuggling and } \\
\text { Indian traders are selling } \\
\text { cattle on credit } \\
\text { T8.Spread of cattle diseases } \\
\text { T9. Lack of veterinary check of } \\
\text { animal before and after } \\
\text { slaughter and low hygienic } \\
\text { handling the meat lead to } \\
\text { health risk for consumers }\end{array}$ & $\begin{array}{l}\text { ST Strategies(competitive)-based } \\
\text { on sector's advantages use } \\
\text { overcoming opportunities of external } \\
\text { environment's non-pleasant } \\
\text { influence } \\
\text { ST 1. (S1,S2,S3, S7, T1,T4,T6) } \\
\text { Development contract framing model } \\
\text { with provision of self help group } \\
\text { formation, skill development, provide } \\
\text { input and finally market linkage and } \\
\text { increasing the role of safe guards to } \\
\text { guarantee the safeties of cattle } \\
\text { fattening in legal way }\end{array}$ & $\begin{array}{l}\text { WT Strategies(defensive) - by } \\
\text { improving its weak point in } \\
\text { sector's external environment's } \\
\text { non-pleasant condition and } \\
\text { overcome its consequences } \\
\text { WT. 1. (W1,W2, W3, W5, } \\
\text { T1,T5,T6) } \\
\text { Optimizing government role by } \\
\text { supporting programs, which } \\
\text { increase agribusiness potential } \\
\text { with an integration system, } \\
\text { increasing knowledge and } \\
\text { ability of ranchers by training } \\
\text { programs and assistance. } \\
\text { Long-term strategy }\end{array}$ \\
\hline
\end{tabular}

Source: Authors own illustration 2014 


\section{Choosing Priority Strategy by the QSPM matrix}

QSPM matrix is made in order to choose and determine which strategy is the best to recommend to beef cattle development.

Table 4. Quantitative strategies planning matrix (QSPM)

\begin{tabular}{|c|c|c|c|c|c|c|c|c|c|c|}
\hline \multirow{3}{*}{$\begin{array}{l}\text { SI. } \\
\text { No. }\end{array}$} & \multirow[t]{3}{*}{ External and internal factors } & \multirow[t]{3}{*}{ Weight } & \multicolumn{8}{|c|}{ STRATEGY - SO } \\
\hline & & & \multicolumn{2}{|c|}{ Strategy-I } & \multicolumn{2}{|c|}{ Strategy-II } & \multicolumn{2}{|c|}{ Strategy-III } & \multicolumn{2}{|c|}{ Strategy-IV } \\
\hline & & & AS & TAS & AS & TAS & AS & TAS & AS & TAS \\
\hline & Opportunities & $\mathrm{a}$ & $\mathrm{b}$ & $C=a^{*} b$ & $\mathrm{~d}$ & $e=a^{*} d$ & $f$ & $g=a * f$ & $\mathrm{~h}$ & $I=a^{*} h$ \\
\hline $\mathrm{O} 1$ & Potential demand for beef over the country. & 0.014 & 3 & 0.042 & 4 & 0.056 & 4 & 0.056 & 2 & 0.028 \\
\hline $\mathrm{O} 2$ & Government support to develop beef cattle & 0.041 & 4 & 0.164 & 2 & 0.082 & 4 & 0.164 & 4 & 0.164 \\
\hline $\mathrm{O} 3$ & $\begin{array}{l}\text { Domestic and foreign private sector interested to } \\
\text { invest. }\end{array}$ & 0.061 & 3 & 0.183 & 3 & 0.183 & 3 & 0.183 & 3 & 0.183 \\
\hline $\mathrm{O} 4$ & $\begin{array}{l}\text { High potential for profitable slaughter and processing } \\
\text { business }\end{array}$ & 0.051 & 4 & 0.204 & 3 & 0.153 & 2 & 0.102 & 3 & 0.153 \\
\hline O5 & High value addition potential & 0.071 & 4 & 0.284 & 3 & 0.213 & 3 & 0.213 & 4 & 0.284 \\
\hline O6 & $\begin{array}{l}\text { Consumers express more interest and are willing to } \\
\text { pay for safe food }\end{array}$ & 0.074 & 3 & 0.222 & 4 & 0.296 & 2 & 0.148 & 4 & 0.296 \\
\hline $\mathrm{O} 7$ & $\begin{array}{l}\text { Domestic oriented processing plants have options to } \\
\text { differentiate and diversify their products to satisfy some } \\
\text { of the untapped markets }\end{array}$ & 0.067 & 3 & 0.201 & 4 & 0.268 & 3 & 0.201 & 3 & 0.201 \\
\hline $\mathrm{O} 8$ & Labor intensive and employment opportunities & 0.065 & 4 & 0.260 & 3 & 0.195 & 3 & 0.195 & 3 & 0.195 \\
\hline \multirow[t]{2}{*}{ O9 } & $\begin{array}{l}\text { Scope exists for developing backward and forward } \\
\text { linkage. }\end{array}$ & 0.055 & 3 & 0.165 & 3 & 0.165 & 2 & 0.11 & 4 & 0.22 \\
\hline & Threats & & & & & & & & & \\
\hline $\mathrm{T} 1$ & Low productivity & 0.063 & 1 & 0.063 & 2 & 0.126 & 4 & 0.252 & 4 & 0.252 \\
\hline $\mathrm{T} 2$ & Increase in feed prices & 0.043 & 1 & 0.043 & 1 & 0.043 & 3 & 0.129 & 4 & 0.172 \\
\hline T3 & Increase in cattle prices & 0.065 & 1 & 0.065 & 3 & 0.195 & 3 & 0.195 & 3 & 0.195 \\
\hline $\mathrm{T} 4$ & Absence of pasture lands & 0.064 & 2 & 0.128 & 2 & 0.128 & 4 & 0.256 & 3 & 0.192 \\
\hline T5 & Poor access to credit & 0.061 & 2 & 0.122 & 3 & 0.183 & 4 & 0.244 & 4 & 0.244 \\
\hline T6 & High transportation cost (Illegal toll for cattle marketing) & 0.057 & 1 & 0.057 & 3 & 0.171 & 3 & 0.171 & 3 & 0.171 \\
\hline $\mathrm{T} 7$ & $\begin{array}{l}\text { Beef cattle smuggling and Indian traders are selling } \\
\text { cattle on credit }\end{array}$ & 0.046 & 2 & 0.092 & 3 & 0.138 & 3 & 0.138 & 4 & 0.184 \\
\hline T8 & Spread of cattle diseases & 0.041 & 2 & 0.082 & 2 & 0.082 & 3 & 0.123 & 3 & 0.123 \\
\hline \multirow[t]{2}{*}{ T9 } & $\begin{array}{l}\text { Lack of veterinary check of animal before and after } \\
\text { slaughter and low hygienic handling the meat lead to } \\
\text { health risk for consumers }\end{array}$ & 0.061 & 1 & 0.061 & 3 & 0.183 & 4 & 0.244 & 4 & 0.244 \\
\hline & Strength & & & & & & & & & \\
\hline S1 & Domestically produced & 0.059 & 4 & 0.236 & 2 & 0.118 & 3 & 0.177 & 2 & 0.118 \\
\hline S2 & Beef cattle are renewable natural & 0.064 & 4 & 0.256 & 2 & 0.128 & 3 & 0.192 & 2 & 0.128 \\
\hline S3 & Large number of labour force. & 0.057 & 4 & 0.228 & 3 & 0.171 & 3 & 0.171 & 1 & 0.057 \\
\hline S4 & Government is committed to develop the sector & 0.065 & 3 & 0.195 & 3 & 0.195 & 2 & 0.130 & 2 & 0.130 \\
\hline S5 & High interest beef cattle rearing among respondents & 0.056 & 3 & 0.168 & 2 & 0.112 & 2 & 0.112 & 2 & 0.112 \\
\hline S6 & $\begin{array}{l}\text { Rapid growth supermarkets, superstore, restaurant and } \\
\text { tourist hotel. }\end{array}$ & 0.052 & 4 & 0.208 & 2 & 0.104 & 1 & 0.052 & 1 & 0.052 \\
\hline S7 & Availability of innovative technology & 0.046 & 3 & 0.138 & 3 & 0.138 & 3 & 0.138 & 2 & 0.092 \\
\hline S8 & Favorable geographical location, climate and breed & 0.054 & 4 & 0.216 & 3 & 0.162 & 2 & 0.108 & 3 & 0.162 \\
\hline \multirow[t]{2}{*}{ S9 } & Consumers preference for beef & 0.041 & 3 & 0.123 & 4 & 0.164 & 3 & 0.123 & 3 & 0.123 \\
\hline & Weakness & & & & & & & & & \\
\hline W1 & Lack of feed and fodder & 0.064 & 3 & 0.192 & 3 & 0.192 & 3 & 0.192 & 2 & 0.128 \\
\hline W2 & Lack of meat processing knowledge & 0.053 & 4 & 0.212 & 2 & 0.106 & 1 & 0.053 & 3 & 0.159 \\
\hline W3 & Prevalence of Anthrax diseases & 0.048 & 2 & 0.096 & 3 & 0.144 & 1 & 0.048 & 3 & 0.144 \\
\hline W4 & Lack of sufficient and proper slaughter houses & 0.063 & 2 & 0.126 & 3 & 0.189 & 2 & 0.126 & 4 & 0.252 \\
\hline W5 & $\begin{array}{l}\text { Limitations of supporting institutions related to beef } \\
\text { cattle }\end{array}$ & 0.058 & 2 & 0.116 & 4 & 0.232 & 2 & 0.116 & 2 & 0.116 \\
\hline W6 & Inadequate institutional support & 0.055 & 2 & 0.11 & 3 & 0.165 & 2 & 0.11 & 3 & 0.165 \\
\hline W7 & Lack of working capital & 0.064 & 2 & 0.128 & 2 & 0.128 & 2 & 0.128 & 3 & 0.192 \\
\hline W8 & Limited number of local cattle breed & 0.053 & 2 & 0.106 & 4 & 0.212 & 2 & 0.106 & 2 & 0.106 \\
\hline \multirow[t]{2}{*}{ W9 } & No organized marketing system & 0.048 & 3 & 0.144 & 4 & & 1 & 0.048 & 2 & 0.096 \\
\hline & Total of attractiveness score (TAS) & & & 5.436 & & 5.520 & & 5.254 & & 5.833 \\
\hline
\end{tabular}

N.B: Attractiveness score (AS) is: $1=$ not attractive, 2=somewhat attractive, $3=$ reasonably attractive, and $4=$ highly attractive 
Based on the SWOT matrix analysis these strategies chosen to be implementing to the real condition of beef cattle development Table 4 shows that the value TAS is 5.833 , which is chosen as best strategy to develop beef cattle agribusiness. The implementation of strategy IV is supported by strategies I, II and III because in order to streamline the provision of developing integrated strategy involving farmers, actors and meat processors in the value chain. These findings are consistent with the results of Ananto et al, (2011). Furthermore the researchers recommends improving beef productivity through transferring innovative beef fattening technology, increase support services and sustainable market linkage. New meat processing firms or abattoirs may be developed by PPP model in producing areas and adopting marketing strategies for increasing share in domestic and foreign markets share. This model should be supported by government through providing advanced technologies, for cattle fattening, feed processing and meat processing, which would lead to innovative beef cattle agribusiness.

\section{Strategy to improve beef cattle agribusiness}

Table 5 provides a summary of key findings that impede the competitiveness of beef cattle agribusiness in the study areas necessary interventions doing with the concerned agencies for taking necessary actions.

Table 5. Strategy to improve of beef cattle agribusiness

\begin{tabular}{|c|c|c|}
\hline Issue/Barriers/Problems & Interventions/Solutions & Actions taken by \\
\hline \multicolumn{3}{|l|}{ A. Technical problems and solution } \\
\hline \begin{tabular}{|ll} 
1. & Lack of beef breeds \\
2. & Lack of standard cattle fattening \\
& technologies and feed ingredients \\
& at local level \\
3. & Lack of veterinary service \\
4. & Marketing skill and capacity \\
5. & Use of unauthorized growth \\
& promoter for cattle fattening \\
6. & Lack of slaughtering and \\
& processing facilities
\end{tabular} & $\begin{array}{l}\text { 1. Development of beef breeds for increased productivity at } \\
\text { farm level. } \\
\text { 2. Encourage the rural poor cattle farmers in cattle fattening } \\
\text { using improved technologies, quality beef production and } \\
\text { establishing linkages with markets actors. } \\
\text { 3. Increased ratio of vaccination and mapping for disease } \\
\text { prediction } \\
\text { 4. Develop local service provider or private } \\
\text { 5. Use of fattening techniques towards organic cattle } \\
\text { farming. } \\
\text { 6. Policy update to discourage used of growth promoter for } \\
\text { fattening } \\
\text { 7. Arrangement of training for butchers on scientific methods } \\
\text { of slaughtering, meat processing and preservation } \\
\text { technique. } \\
\text { 8. Bangladesh Agricultural Universities and BLRI should } \\
\text { encourage research in various aspects of cattle farming }\end{array}$ & $\begin{array}{l}\text { Government } \\
\text { NGOs+ Government } \\
\text { +Private enterprise } \\
\\
\text { Government .+DLS } \\
\text { DLS+ Veterinary } \\
\text { University } \\
\text { NGOs+ Private } \\
\text { enterprise } \\
\text { Government } \\
\text { Government +DLS } \\
\text { Government }\end{array}$ \\
\hline \multicolumn{3}{|l|}{ B. Economic problems and solution } \\
\hline $\begin{array}{l}\text { 1. Lack of working capital for beef } \\
\text { cattle agribusiness } \\
\text { 2. Lack of coordination of different } \\
\text { actors } \\
\text { 3. Lack of processing factory } \\
\text { 4. Lack of contract farming and self } \\
\text { help groups }\end{array}$ & $\begin{array}{l}\text { 1. Arrangement of adequate amount of credit at low rate of } \\
\text { interest. } \\
\text { 2. Facilitate and linking farmers with different agribusiness } \\
\text { operators (Company) and traders. } \\
\text { 3. Encourage entrepreneurs is established meat processing } \\
\text { factories in north Bengal } \\
\text { 4. Organize self help group for access to inputs and support } \\
\text { service with provision of contract farming. } \\
\text { 5. Development of backward and forward linkage system to } \\
\text { help improvement of existing cattle farming system into } \\
\text { private enterprises. }\end{array}$ & $\begin{array}{l}\text { NGOs + Banks } \\
\text { NGOs+ Dept. of } \\
\text { Extension } \\
\text { Private enterprise } \\
\text { Farmers and NGOs } \\
\text { NGOs + Private sector }\end{array}$ \\
\hline \multicolumn{3}{|l|}{ C. Marketing problems and solution } \\
\hline \begin{tabular}{|l} 
1. Lack of cattle market infrastructure \\
and disposal system of waste \\
products \\
2. Lack of marketing and distribution \\
system \\
3. Processing in unhygienic condition
\end{tabular} & $\begin{array}{l}\text { 1. Improve market infrastructure } \\
\text { 2. Transparence of price, transaction method and market } \\
\text { information between farmers and agribusiness actors } \\
\text { 3. Organize and upgrade meat distribution network } \\
\text { 4. Policies to encourage beef cattle fattening towards high } \\
\text { quality, safety and competitive meat price for high income } \\
\text { domestic market Dhaka, Chittagong etc. } \\
\text { 5. Encourage private sector to establish mechanized } \\
\text { slaughter house. }\end{array}$ & $\begin{array}{l}\text { Government } \\
\text { Private enterprise + } \\
\text { media } \\
\text { Private enterprise } \\
\text { Government } \\
\\
\text { Government }\end{array}$ \\
\hline
\end{tabular}

Source: Field survey 2014 


\section{Conclusion}

Based on SWOT analysis the weighted scores are1.725, 2.438, 1.768, and 0.842 for opportunities, threats, strength and weakness respectively. Opportunities and strength scores are higher than the threats and weakness of beef cattle agribusiness. The results indicate the great opportunity to explore the beef cattle agribusiness. From the QSPM matrix analysis results show that SO strategy is the best strategy among the four strategies and total attractiveness score (TAS) is 5.833. So the strategy IV is chosen and other strategies will support strategy IV. Some recommendations to enhance beef cattle agribusiness in the study area are forwarded below:

- Preparing strategic plans for beef cattle agribusiness combination with producer and meat processor by public private partnership.

- Formal production- marketing contract farming of beef cattle may be introduced.

- Encourage investment on commercial cattle fattening, meat processing, butcher equipment and distribution network

- Arrangement for access to institutional credit with reasonable interest rate may help to enhance production of beef cattle

- Introduction of suitable/appropriate vehicles for transportation of cattle during buying and selling.

- Encourage donor agencies for taken development projects like Samiriddhi, SDVC, CLP, M4P, Value chain etc

- Raising awareness among the farmers, traders, value chain actors to use beef fattening technology.

\section{Acknowledgements}

The authors are thankful to the beef cattle entrepreneurs and different agribusiness actors in the study areas who participated in the study. The author also thankful to Mr. Hanny Jørgensen, Danish Agricultural Advisory Service (DAAS), Denmark for his valuable comments to improve the paper

\section{References}

Achmad, M., Hartoyo, Arifin, B., Didu, S.M. 2012. "Model Policy Design for the Beef Cattle Development in South Sulawesi" Bogor Agricultural University, Indonesia.

Ananto, N., Eriyatno, Marimin, Arief, D. 2011. "Model Integration Policy Development Planning Livestock - Beef Case Study of SelfSufficiency", Journal of Development Planning,17(3).

Bamualim, A.M., Trisnamurti, B., Talib, C. 2008. "Beef Cattle Development Direction in Indonesia", Journal of Agricultural Research 12 (2): 22-28.

David, M.E., David, F.R. 2009. "The Quantitative Strategic Planning Matrix (QSPM) Applied to a Retail Computer Store" The Coastral Business Journal, Vol.8, No. 1 PP:42-52.

David, F,R. 2009. "Strategic Management: Strategic Management: Concepts 12th edition Translation by DonoSunardi” . Jakarta: SalembaEmpat.

Erdenebiled, U. 2008. "Report on Beef Sub-sector Value Chain Analysis," Rural Agri-Business Support Program, Ulaanbaatar, USDA.

Gunawan. 2001. "Model and Strategy of Agribusiness Research Cooperation on Beef Cattle in Globalization Period," http: // farm solution. Blog spot.com /2008/ 11/model-and-strategy-of- agribusiness.

Prastiti, R.A., Rahayu, W.S.P, Arip, W. 2012. "Agribusiness Development Strategies of Beef Cattle in Blora District," e-Journal Agrista, http://agribisnis.fp.uns.ac.id.

Santosa U. 2006. "Development of Bali cattle in the Livestock Management", Journal of Agricultural Research 22 (2) : 34-40.

Suryana, Taheri, S.N., Mighani, A.M. 2009. "Model and Strategy of Agribusiness Research Cooperation on Beef Cattle in Globalization Period," http://www. ukessays. Com / essays /business/swot-analysis.php.

Kangas, J., Kurtila, M., Kajanus, M., Kangas, A. 2000. "Evaluating the management strategies of a forestland estate-the S-O-S approach", Journal of Environmental Management 69، pp 349-358.

Wheelen,T.L., Hunger, J.D. 1995. "Strategic Management and Business Policy”, Addison - Wesley, Reading, MA. 